\title{
Spatial Analysis of Leptospira in Rats, Water and Soil in Bantul District Yogyakarta Indonesia
}

\author{
Hadi Sumanta1,2*, Tri Wibawa ${ }^{3}$, Suwarno Hadisusanto ${ }^{4}$, Anik Nuryati ${ }^{5}$, Hari Kusnanto ${ }^{6}$ \\ ${ }^{1}$ Center for Environmental Health Engineering, and Disease Control, Yogyakarta, Indonesia \\ ${ }^{2}$ Student of Doctoral Program, Faculty of Medicine, Gadjah Mada University, Yogyakarta, Indonesia \\ ${ }^{3}$ Department of Microbiology, Faculty of Medicine, Gadjah Mada University, Yogyakarta, Indonesia \\ ${ }^{4}$ Department of Biology, Faculty of Biology, Gadjah Mada University, Yogyakarta, Indonesia \\ ${ }^{5}$ Department of Health Analyst, Yogyakarta Health Polytechnic, Yogyakarta, Indonesia \\ ${ }^{6}$ Department of Public Health, Faculty of Medicine, Gadjah Mada University, Yogyakarta, Indonesia \\ Email: ${ }^{*}$ hadisumanta@yahoo.com
}

Received 24 December 2014; accepted 15 January 2015; published 21 January 2015

Copyright (C) 2015 by authors and Scientific Research Publishing Inc.

This work is licensed under the Creative Commons Attribution International License (CC BY).

http://creativecommons.org/licenses/by/4.0/

(c) (i) Open Access

\section{Abstract}

Leptospirosis is a potential threat to public health. An increasing number of people infected with Leptospira were reported in Bantul District, Yogyakarta special region with a case fatality rate (CFR) of 7.8\%. Infected areas in the district have increased from 2 to 15 sub districts. Leptospirosis is caused by Leptospira bacteria and spread by direct contact with infected rodents and indirect contact through contaminated water or soil. Leptospira in rats, water and soil were detected using real-time quantitative polymerase chain reaction (qPCR). The sites of sampled materials were geocoded using Global Positioning System (GPS). Spatial analysis was used to predict the spread of Spira. This study aims to perform the mapping, clustering, and predicting the spread of Leptospira in Bantul Yogyakarta Indonesia. Data were collected from three sub-districts: Sedayu, Sewon and Bantul. The result showed that $\mathbf{3 8 . 0 4 \%}$ from 368 samples were Spira positive. There were four significant clusters of infection spread source. Spira is predicted to spread in, and out from, Bantul District.

\section{Keywords}

Leptospirosis, Leptospira, Rats, Water, Soil, Spatial Analysis

\footnotetext{
${ }^{*}$ Corresponding author.
}

How to cite this paper: Sumanta, H., Wibawa, T., Hadisusanto, S., Nuryati, A. and Kusnanto, H. (2015) Spatial Analysis of Leptospira in Rats, Water and Soil in Bantul District Yogyakarta Indonesia. Open Journal of Epidemiology, 5, 22-31. 


\section{Introduction}

Leptospirosis is a zoonoses infectious disease caused by the direct spiral shaped microorganisms called Leptospira [1]-[3]. Transmission of the disease can be through direct contact with urine and body fluids of infected animals, or through indirect contact with environmental water and soil contaminated with the bacteria Leptospi$r a$ [4]-[6]. Michna and Faine, revealed that the urine of infected animals or carrier Spira healthy environment can contaminate the water, soil, grass, drinking water and food [7]-[9]. Leptospira lives in the kidneys and the urine is the source of infection when the reservoir is issue the urine in water or soil environments [10]-[12].

Leptospira can live up to several months in water and plays an important role as a source of transmission of leptospirosis. Spira needs an optimal environment to live and to reproduce such as a moist atmosphere, temperatures around $25^{\circ} \mathrm{C}$, and $\mathrm{pH}$ near neutral $( \pm 7)$. Dry weather conditions, strong sunlight, water and soil $\mathrm{pH}$ outside the range of 6.2 to 8.0 do not support the growth of Leptospira [4] [13] [14].

Rats are the reservoir with chronic leptospirosis infection. The infection is transmitted from rat to an other through direct contact at a young age or mature. According to Rejeki, L. icterohaemorrhagiae species were found in Bandicota indica and Rattus diardii, meanwhile L. Ballum species were found in Mus musculus [15]. Rats are suspected to have an important role in the incidence of leptospirosis are $R$. norvegicus, $R$. diardii, Suncus murinus and R. exulans [16].

Data from the Regional Health Office Yogyakarta showed that Leptospirosis cases rising during the last 5-year period (2009 - June 2013). In 2009, there were 10 cases in the 2 villages. An outbreak of leptospirosis occurred in 2010 with 116 cases in 43 villages. For the next year increased 154 cases and widespread in 51 villages. Cases declined in 2012 to 48 cases in 27 villages, but in the early semester of 2013 the case raised to 51 cases in 24 villages [17]. Syamsumin [18] reported that the outbreak occurred due to exposure to water irrigation like canal or river or pond, the presence of rats in the work environment and the presence of livestock manure in the house. Geographical conditions that favor outbreaks are agricultural lands such as rice fields, plantations and moor, and the presence of pools, ponds and swamps, and rainfall average of $11 \mathrm{~mm}$ days each month [18].

The spread of Leptospira in environment related to epidemiological aspects and geographical region. Spatial analysis can be used to determine the spread and clustering and to predict the incidence of leptospirosis in a region [19]. Spatial analysis with geographical information systems approach (GIS) has been widely applied in various studies in order to control leptospirosis. Mapping patterns of this disease is often done to determine the location of the source of infection. Tunissea, Sunaryo, Melani dan Fuadi, has conducted research on spatial analysis of patients with leptospirosis on the environment. These studies mapped the distribution patterns of patients with leptospirosis. Distribution of leptospirosis tends to follow the river flow pattern with high rainfall. Leptospirosis cases are found in slums and in area were rats are found [19]-[22].

Accordingly, this study examines whether there is a pattern of distribution and clustering of Leptospira bacteria, as well as to predict distribution patterns Leptospira bacteria in Sedayu, Bantul and Sewon Sub District. This study can be used as a guidance to control leptospirosis.

\section{Methods}

\subsection{Study Site and Sample}

This research was conducted in Sedayu, Bantul and Sewon Sub District which is highly endemic areas leptospirosis. Samples were determined based on the presence of patients with leptospirosis in Sedayu, Bantul and Sewon Sub District, from Hospital medical records and Health Office Bantul District in 2013. Samples in this study were rats, water and soil in the area where the patient lived. The number of rats in each district is calculated based on the sample formula according to Dohoo, were 30 rats [23]. Water and soil samples are taken from 1 - 3 points in around the site of rats catched. Determination of sampling sites was based on the presence of signs such as rat hole, trace of the rat, and rat droppings.

\subsection{Data Collection and Analysis}

Leptospirosis patient data obtained from District health offices and Hospitals Bantul regency in 2013, based on medical record data on the clinical and laboratory diagnosis by serological tests using dot lepto tek lepto tek dri or lateral flow. Catching mice using traps conducted around the patient's residence. Traps were installed in 
places that there are signs of the rat both inside and outside the home or in a rice field for 3 nights to allow the rat entering the trap. One trap in stalled at any place or home with a spacious 0.015 to 0.035 ha, and each multiplication added one trap. While in paddy fields, the trapis installed at every 0.85 to 2.1 ha of paddy fields [24] [25]. Water and soil samples were taken around the location ofthe arrest the mouse with a radius of \pm 50 meters around the house and \pm 100 meters around the field. Criteria for water or soil samples to be taken where there were signs ofthe rat, such as the presence of a hole or nest of the rat, the precense of traces of the rat, and the presence of rat droppings. Water and soil sampling conducted in the morning at approximately 6:00 a.m. to 9:00 a.m.in the morning before the sun directly in to water or soil [24]. Determination of the presence of Leptospira bacteria in the samples was conducted by qPCR using appropriate primers. Forward primer is ${ }^{, 171}$-CCCGCGTCCGATTAGC-3'. Reverse primer is $5^{, 258}$-TCCATTGTGGCCGR ${ }^{\mathrm{A} / \mathrm{G}}$ ACAC-3'. The probe is ${ }^{2}{ }^{205}(\mathrm{FAM})$ CTCACCAAGGCG ACGATCG GTAGC ${ }^{228}$-3' (TAMRA), FAM 6-carboxy-fluorescein, TAMRA 6-carboxytetramethyl-rhodamine [26]. Determination of coordinates using GPS performed on place of the rat was found, and water and soil samples were taken.

Data were analyzed qualitatively and quantitatively using computers, and were presented in the form of description and tables. Distribution patterns and clustering of bacteria Leptospira were analyzed by spatial analysis approach using ArcGIS software assistance, SaTScan and CrimeStat program.

\subsection{Ethical Clearance}

This study has obtained ethical permission (ethical clearance) for medical research from the Ethics Committee of Faculty of Medicine Gadjah Mada University.

\section{Result}

Three sub-districts of Bantul (includes Sedayu, Sewon, Bantul) purple were endemic leptospirosis areas that used for our research (Figure 1). Geographically, Bantul is located between $07^{\circ} 44^{\prime} 04^{\prime \prime}$ - 08 $00^{\circ} 27^{\prime \prime}$ South Latitude and $110^{\circ} 12^{\prime} 34^{\prime \prime}-110^{\circ} 31^{\prime} 08^{\prime \prime}$ East Longitude in the southern part of Yogyakarta. Bantul district has an area of $50.85 \mathrm{~km}^{2}$ or 50.685 ha, which is composed of 17 districts and divided in to 75 villages and 933 hamlets.

Bantul district is an area that suitable for agriculture. But in this area there are many puddles and ditches with water that does not flow well. It is suitable for the development of Leptospira bacteria. Figure 2 shows the location of the data in the form of rice fields and ditches that there are many puddles. This location is also

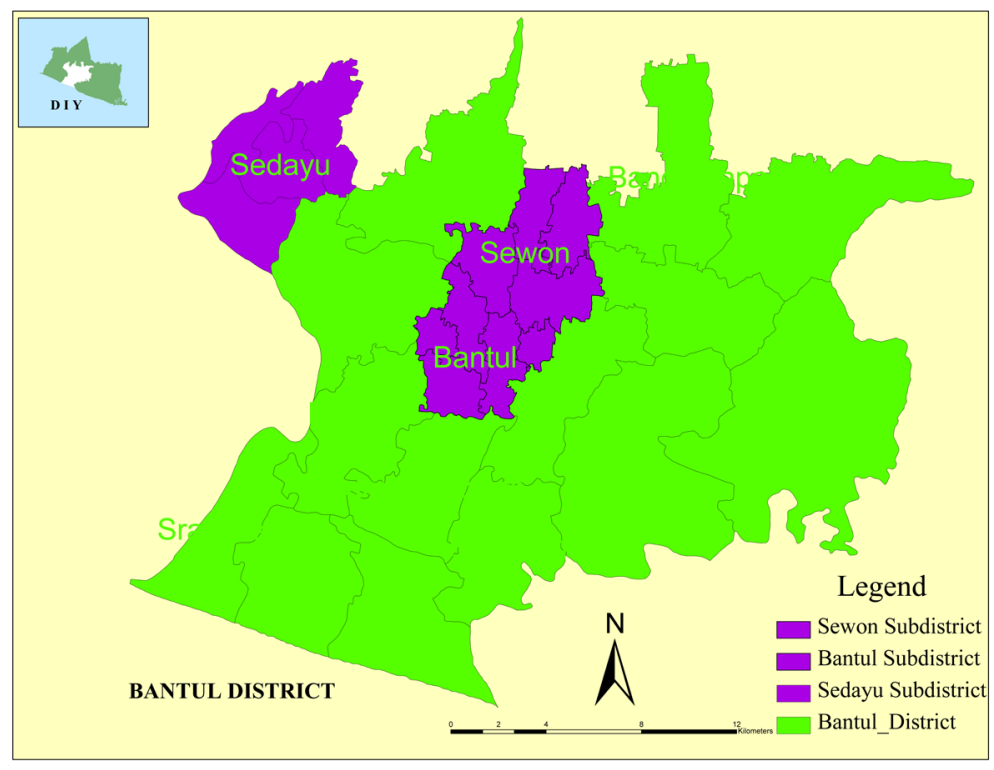

Figure 1. The study area at three sub districts in Bantul district. The purple color indicates the study area, Sub District of Bantul, Sewon and Sedayu. Green color, Bantul Regency excluding research area. 


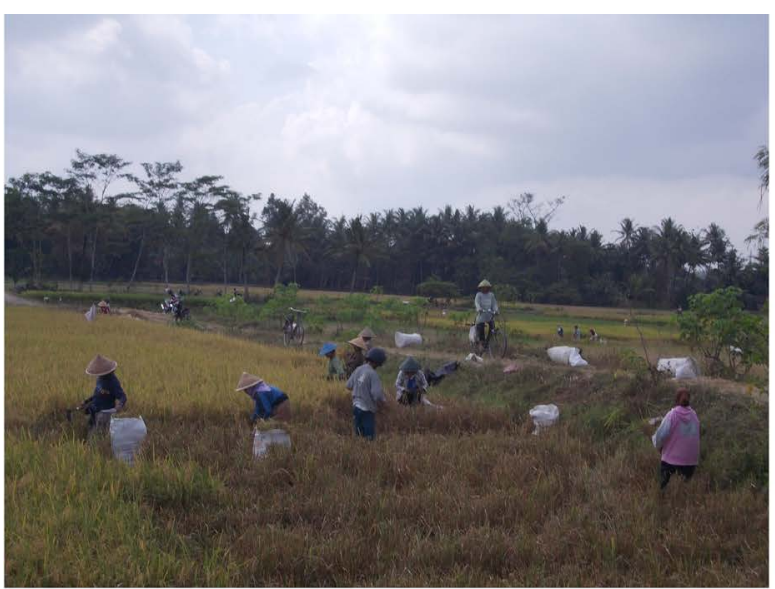

(a)

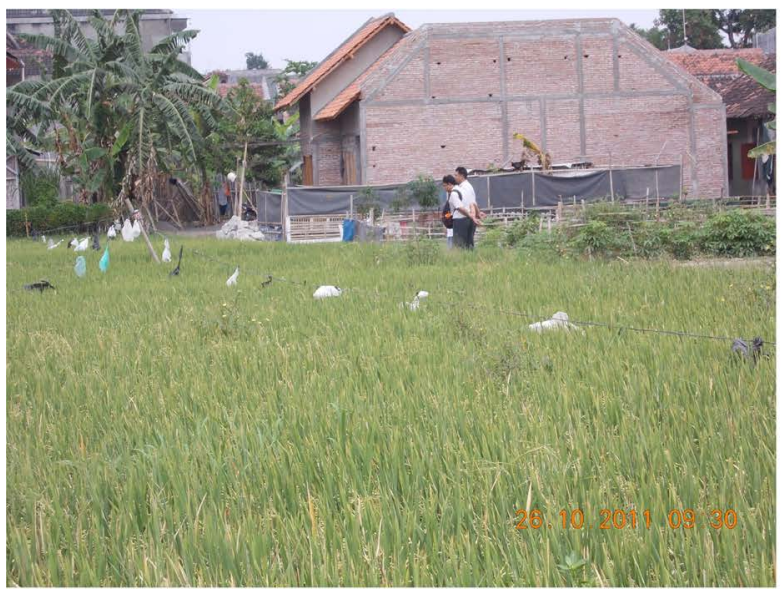

(b)

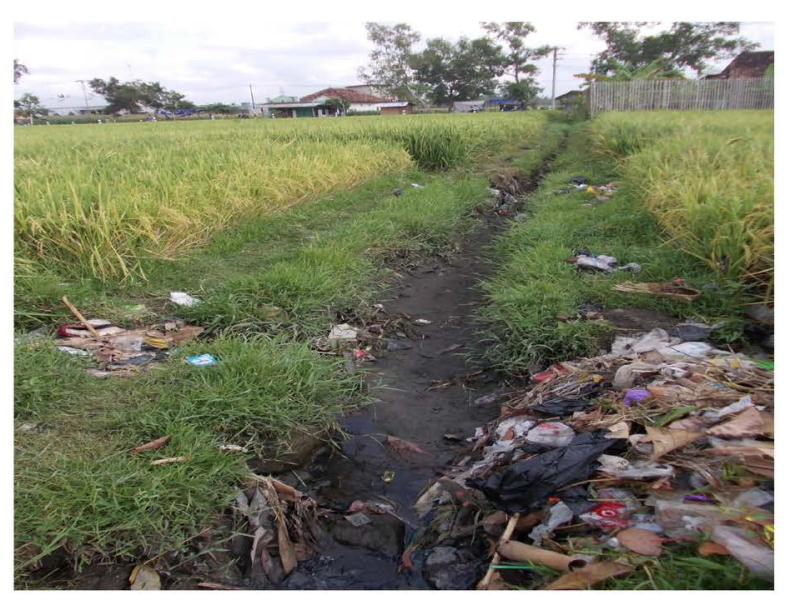

(c)

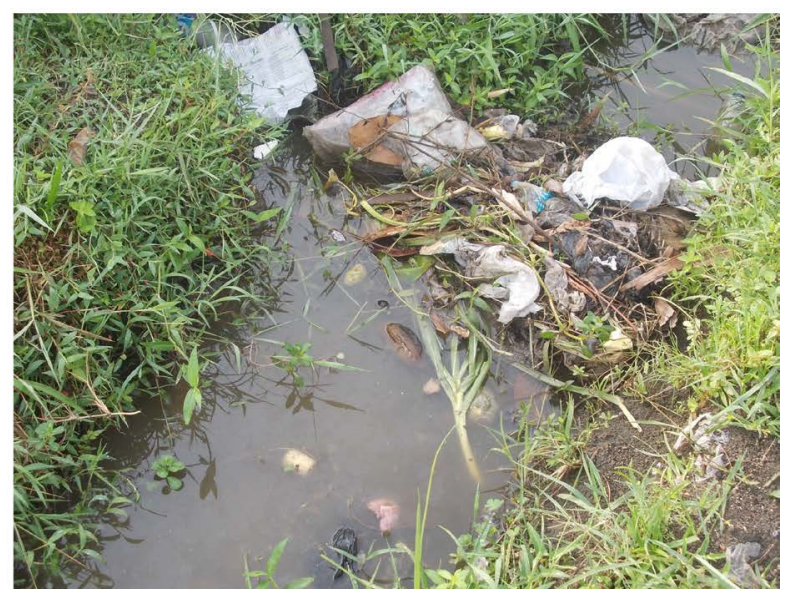

(d)

Figure 2. Images of the location, the source of exposure to Leptospira bacteria. (a) Rice field area. Farmers are vulnerable to Leptospira exposure. (b) Rice fields as a source of infection for the surrounding community. (c) Garbage in the rice field is a source of leptospirosis infection. (d) Puddles in the fields as a source of infection.

suitable for the habitat of the rat as a reservoir host of Spira. These conditions are potentially as place of Leptospira spread and transmission of leptospirosis in Bantul District.

Data collection was conducted from September to December 2013. There was found 18 patients with leptospirosis and 368 samples consisting of 99 samples of the rat, 119 water samples and 150 soil samples. Distribution of patients with leptospirosis in Sedayu, Bantul and Sewon Sub District has been shown in Figure 3.

The examination using qPCR to find bacteria Leptospira performed on 368 samples were successfully collected. The results obtained 140 positive samples pathogenic Leptospira, which consists of 25 (25.25\%) the rat samples, 51 (42.86\%) water samples and 64 (42.67\%) of soil samples. Based on the location of samples collected, Bantul sub-district is an area with the highest positive Leptospira at 51.68\% followed by Sewon Sub District and Sedayu respectively 32.32\% and 25.83\%. Detail of the number of Leptospira in each Sub District has been written as in Table 1.

Determination of coordinates of the samples was taken at the same time when samples had been taking using a GPS device. Distribution of samples obtained shown in Figure 4. Distribution of the sample includes the location where the rat was found, the water and soil were taken.

Buffering pattern identification based on rat Leptospira bacteria, water and soil is shown in Figure 4. Buffering pattern formed indicates areas that have affected the risk of becoming wide spread in accordance with the ability of the rat spread. It appears that this buffer are a past the administrative boundaries, not only in the Bantul district, but also extends to the districts of Sleman and Yogyakarta. 


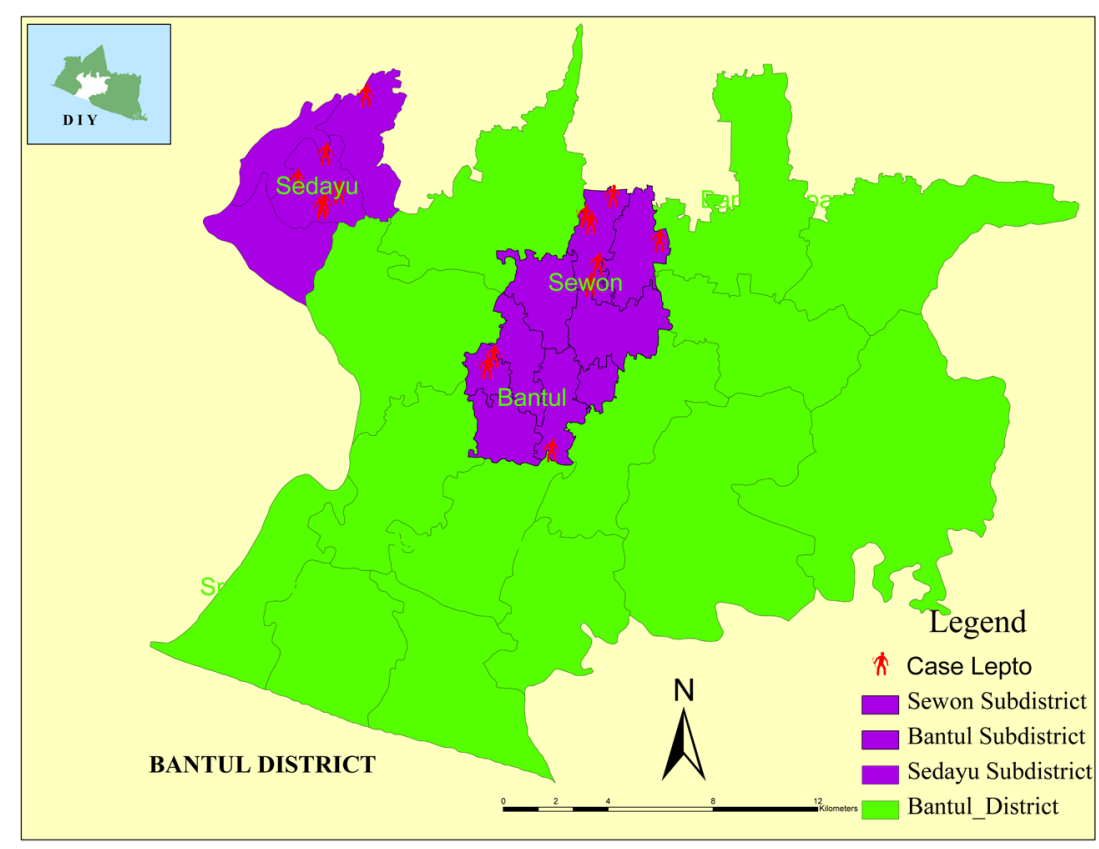

Figure 3. Distribution of patients leptospirosis in the research area of Bantul regency. The red color shows the distribution of patients with leptospirosis. The color purple, the study area in the sub district of Bantul, Sewon and Sedayu. The green color, the district of Bantul which does not include the area of research.

Table 1. The positive Leptospira of rats, water and soil samplesat Sedayu, Bantul and Sewon Sub District.

\begin{tabular}{ccccc}
\hline \multirow{2}{*}{ Sub District } & \multicolumn{4}{c}{ Number of Leptospira/Total Sample } \\
\cline { 2 - 5 } & Rats & Water & Soil & Total \\
\hline Sedayu & $6 / 31(19.35 \%)$ & $13 / 32(40.63 \%)$ & $13 / 36(36.11 \%)$ & $32 / 99(32.32 \%)$ \\
Bantul & $10 / 36(27.78 \%)$ & $\mathbf{2 9 / 5 2 ( 5 5 . 7 5 \% )}$ & $\mathbf{3 8 / 6 1 ( 6 2 . 3 0 \% )}$ & $\mathbf{7 7 / 1 4 9 ( 5 1 . 6 8 \% )}$ \\
Sewon & $9 / 32(28.13 \%)$ & $9 / 35(25.71 \%)$ & $13 / 53(24.53 \%)$ & $31 / 120(25.83 \%)$ \\
Total & $25 / 99(25.25 \%)$ & $51 / 119(42.86 \%)$ & $64 / 150(42.67 \%)$ & $140 / 368(38.04 \%)$ \\
\hline
\end{tabular}

SaTScan analysis shows that there are six clusters of infection source of leptospirosis as shown in Figure 5. The first cluster is located at the position of 7.793400 SL, and 110.276600 EL with a radius of 0:59 miles and there are 7 locations in Sedayu SubDistrict. This cluster is very significant with p value $=0.0000051$. The second cluster is located at the position of $7.905350 \mathrm{SL}$, and $110.329617 \mathrm{EL}$ with a radius of $0.58 \mathrm{~km}$ and there are six locations in Bantul Sub District. This cluster is also very significant with p value $=0.0018$. The third cluster is located at the position of $7.840333 \mathrm{SL}$, and $110.351500 \mathrm{EL}$ with a radius of $1.73 \mathrm{~km}$, and there are ten locations in Sewon Sub District. This cluster is very significant with p value $=0.011$. The fourth cluster is located at the position of $7.843200 \mathrm{SL}$, and $110.377300 \mathrm{EL}$ with a radius of $0.31 \mathrm{~km}$, and there are four locations in Sewon Sub District. This cluster is also very significant with p value $=0.014$. The fifth cluster is located at position $7.888300 \mathrm{SL}$, and $110.361350 \mathrm{EL}$ with a radius of $3.58 \mathrm{~km}$ and there are fifty locations in the district of Bantul. This cluster is not significant with p value $=0.062$. The sixth cluster is located at the position of SL 7.886917, 110.318117 and EL with a radius of $0.40 \mathrm{~km}$, and there are five locations in the district of Bantul. This cluster is not significant with p value $=0.258$.

\section{Discussion}

Transmission of leptospirosis by Leptospira bacteria can be through direct contact with urine and body fluids of infected animals or indirect contact through contaminated water or soil by Leptospira bacteria [4] [6] [27]. Rice 


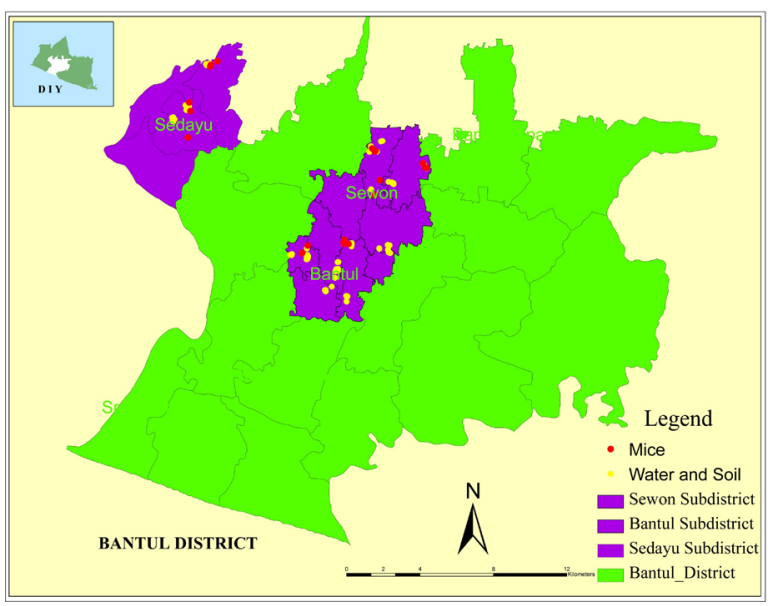

(a)

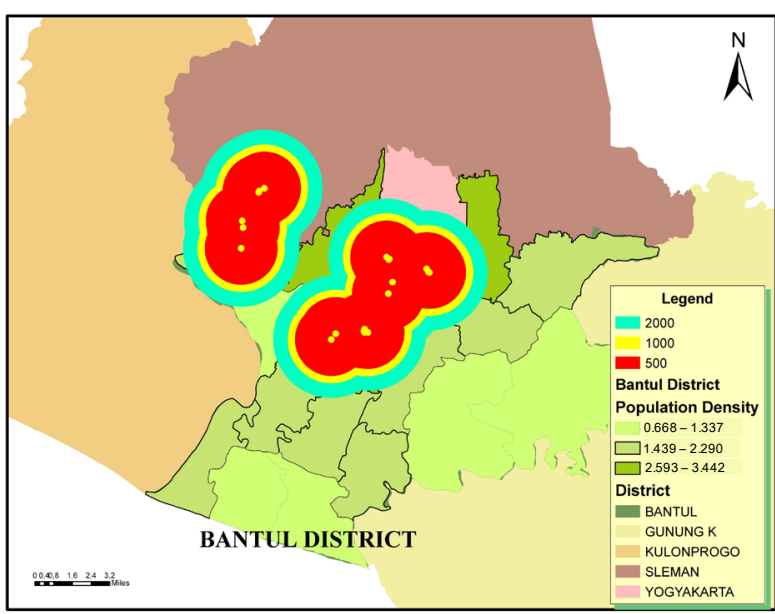

(b)

Figure 4. Distribution of positive samples (a) and positive sample buffer (b) in the three study areas Sedayu subdistrict, Bantul and Sewon, Bantul district. (a) The red color shows the distribution of samples positive mice Spira and yellow colors are water and soil samples were positive Leptospira. (b) Buffer Leptospira positive, blue is the buffer as far as $2 \mathrm{~km}$, yellow as far as $1 \mathrm{~km}$ and red as far as 500 meters. The yellow color is a positive rat samples. The green color shows the population density gradation.

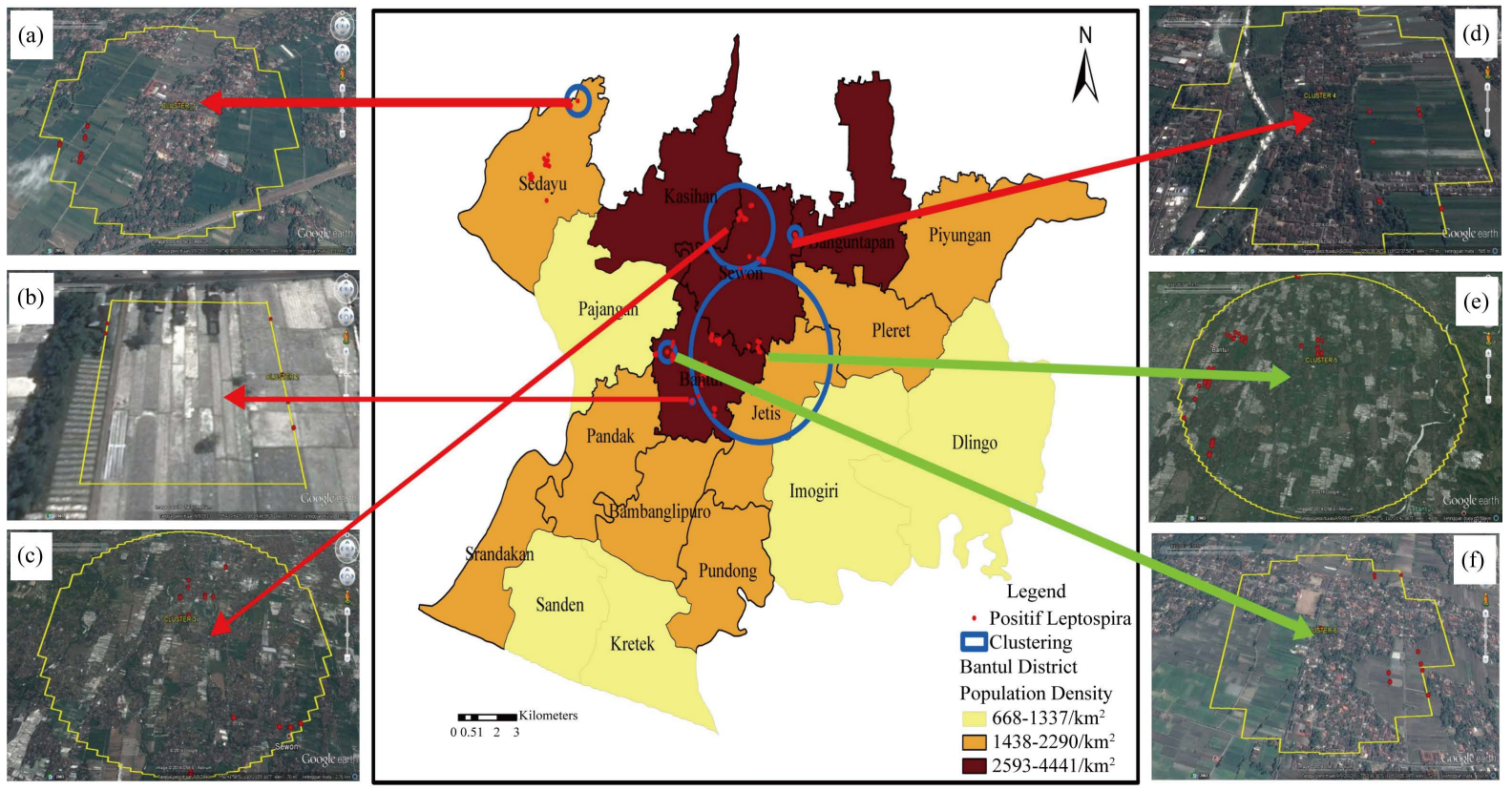

Figure 5. Overview the positive Leptospira clustered in three sub districts of research. (a) is located in District Sedayu. (c) and (d) is located in the sub district Sewon. (b), (e) and (f) located in the sub district of Bantul.

planting season in Bantul District done in conjunction with the rainy season, due to growth requires a lot of water. Puddle during rice grow this optimal conditions for the growth of Leptospira bacteria. According to [4] [13] [14] environment that is often waterlogged is a condition that easily contaminated with Leptospira [4]. Tunisia (2008) and Anies, (2009) stated that the puddle of water in the rice fields is a factor contributing to the occurrence of transmission of leptospirosis. Various factors that support the transmission of Leptospira which are found puddles, fields and bushes or wet grass and animals, especially rodents asa reservoir of Leptospira bacteria source [20] [28].

The presence of Leptospira bacteria in the environment caused by rats urine contamination of Leptospira 
infected [10]-[12], because rats are there servoir and at the same time the main disseminators of Leptospira [29]. This bacteria is out along with the urine when rats explore the habitat to look for food, so the Leptospira bacteria can spread and contaminate water or soil and can infect other rats. Contaminated environment and rats with bacteria Leptospira would potentially be a source of infection and disease transmission sources of leptospirosis in humans [6]-[8]. Leptospira bacteria infect many farmers, farm workers and eel seekers who indulge in the fields [30] [31]. In general (Widarso, et al. 2005) mentions that leptospirosis usually attacks the farmers, plantation workers, mine or ditch workers, and abattoir workers. In Indonesia, the disease includes reemerging disease, so that it can appear sporadically at any time and has the potential to cause outbreaks [32]. Research conducted Simanjuntak et al. (1986) found the incidence of leptospirosis in the transmigration sites in Kuala Cinaku Riau Province have the chances of spread by rats [33].

Risk factors affecting the incidence of leptospirosis are the environmental risk factors of physical, biological environmental risk factors, behavioral factors, socioeconomic factors and health service factors [34]. Factors associated with the incidence Leptospirosis in DIY are work as a farmer, a habit of going to the paddy fields and the rats [30]. Indirect transmission occurs when Leptospira are excreted through the urine or excretion of careers animals to surface water environment, such as puddles, lakes, rivers, swamps, sewage, drainage, and mud puddles. The spread of the disease can spread to other are as due to flood waters contaminated rat urine containing Leptospira bacteria [4]-[6]. In the body of these animals, Leptospira lives in the renal tubules [35] and persist for many years as a chronic infection. This infection is transmitted from animals to another through direct contact. Typically, infection is acquired at a young age, and the prevalence of Leptospira exit through the urine increases with increasing the age of the animal [13]. Cases of leptospirosis associated with the location of land use. Leptospirosis cases are more common in residential land use locations, especially near bodies of water such as rivers, ponds, rice field sand puddles [36].

Leptospira can live up to several months in water and plays an important role as a source of transmission of leptospirosis. Optimal environment to live and reproduce Spira is in a moist atmosphere, temperatures around $25^{\circ} \mathrm{C}$, and $\mathrm{pH}$ near neutral $( \pm 7)$. Conditions of dry air, strong sunlight, and the pH is too low or high $(<6.2->8.0)$ are not favorable atmosphere for the life and growth of Leptospira [4] [14] [37].

Bantul sub-district is an area that has a highest source of transmission of Leptospira (51.68\%) in Bantul compared with two other sub-districts (Sedayu and Sewon), an area of research. Health Service data shows that Bantul sub-district not only have the area with the highest population density, but also have rice field sand locations conducive to rat habitat. Areas with dense population will impact on the high house hold waste be a source of food for rats. Like wise with many residential buildings around the fields and population behavior that less keeping the environment clean are another risk factor leading to high transmission of leptospirosis in Bantul sub-district. In Figure 4, it appears that the distribution of Leptospira in water and soil adjacent to the discovery of rats containing Leptospira. Distribution of Leptospira contaminated water and soil is dependent on home range rat sand high population density in a region.

Poor sanitation conditions such as the presence of midden and the presence of rats is a determinant variable leptospirosis cases. The presence of midden is used as indicators of the presence of rats [38]. This result is consistent with previous studies by Urmimala (2002) in Salvador Brazil stated that he poor shelter condition that is the midden is a risk factor for leptospirosis cases [39]. Barcellos (2001) who concluded that leptospirosis is influenced by the presence of litter, presence of rodents and bacteria Leptospira factors, it is possible there are other biotic factors associated with the incidence [38].

The result of the spatial analysis done by looking at the buffer of the distribution of these cases is an area at risk of the spread of bacteria Leptospira. Leptospira bacteria spread very dependent on rat home range and activities in its habitat. Home range and migration is a distance that commonly taken by rats or area passed rats for foraging activity [40]. Space home range for a mouse can be up to 0.0035 ha, where as field mouse can be up to 2.1 ha. Rats also have the ability to migrate as far as $1-2 \mathrm{~km}$, if there is no food source around the home [40]. Buffer area of the source of infection can be determined based on the distance home range of mice. Figure 5 shows that the location of the buffer is quite large, and has entered the area which is beyond the three subdistricts in Bantul area of research, and even extends to the districts of Sleman and Yogyakarta. This condition is of ten caused by Leptospira bacteria be came wide spread deployment. As we know that the areas around Bantul district is endemic of leptospirosis [17]. This study recommends that need to make a planning a cross borders to control the spread of the bacterium Leptospira Bantul and surrounding region.

Results of SaTScan analysis to see clustering of infection source of leptospirosis in three sub-districts of Bantul 
District obtained 6 clustering distribution of the source of infection. The formations of a strong clustering and significant occur in clusters 1 to 4 for the distribution of sources of infection, where as clusters 5 and 6 were not statistically significant. The existence of a strong cluster grouping indicates that it is likely there has been a process of spreading the bacteria Leptospira in the group, so that the location of the cluster is the site as a potential source of infection leptospiros is. According to Sunaryo (2009), clusters distribution of leptospiros is cases occur under conditions of a polluted environment and land fills with the closest point distance between the case of $9 \mathrm{~m}$ (0.009 $\mathrm{km})$ [21]. Tunissea (2008) showed that the body of water, temperature, light intensity, $\mathrm{pH}$ of water and soil, vegetation and the presence of rats associated with spread leptospirosis [20].

The study also predicts the occurrence of leptospirosis cases. Through the description of the distribution pattern of infection source of leptospirosis, it is known that the distribution of the source of infection can spread to non endemic areas such as parts of Yogyakarta regency and other Sub districts in Bantul. Figure 6 displays the prediction of distribution direction of Leptospira bacteria. Overview the prediction of distribution extends to the southeast which will hit sub-districts in the southeast and the south of Bantul Sub district and partially Yogyakarta City. Location of this prediction of distribution is densely populated areas, so it will most likely be an outbreak Leptospirosis if no appropriate counter measures. This study is inline with research conducted by Nurbaeti in 2012 [38]. The study showed that the distribution of leptospirosis in the border does not spread through the flow of the river, but dealing with the flow of the river in the paddy field [41].

In the report of leptospirosis cases in 2009 showed that leptospirosis cases is most prevalent in Godean subdistrict, Sleman regency. This case from year to year extends and spreads mainly to the east and the south to reach Yogyakarta and Bantul [41] [42]. Looking at the pattern distribution that occurs, it is possible the case will continue to spread, especially in line with the roaming rat as a reservoir host polluting water flow in the paddy fields.

\section{Conclusion}

Leptospira bacteria in the environment are spread through the rats urine infected Spira. It is found 4 clusters

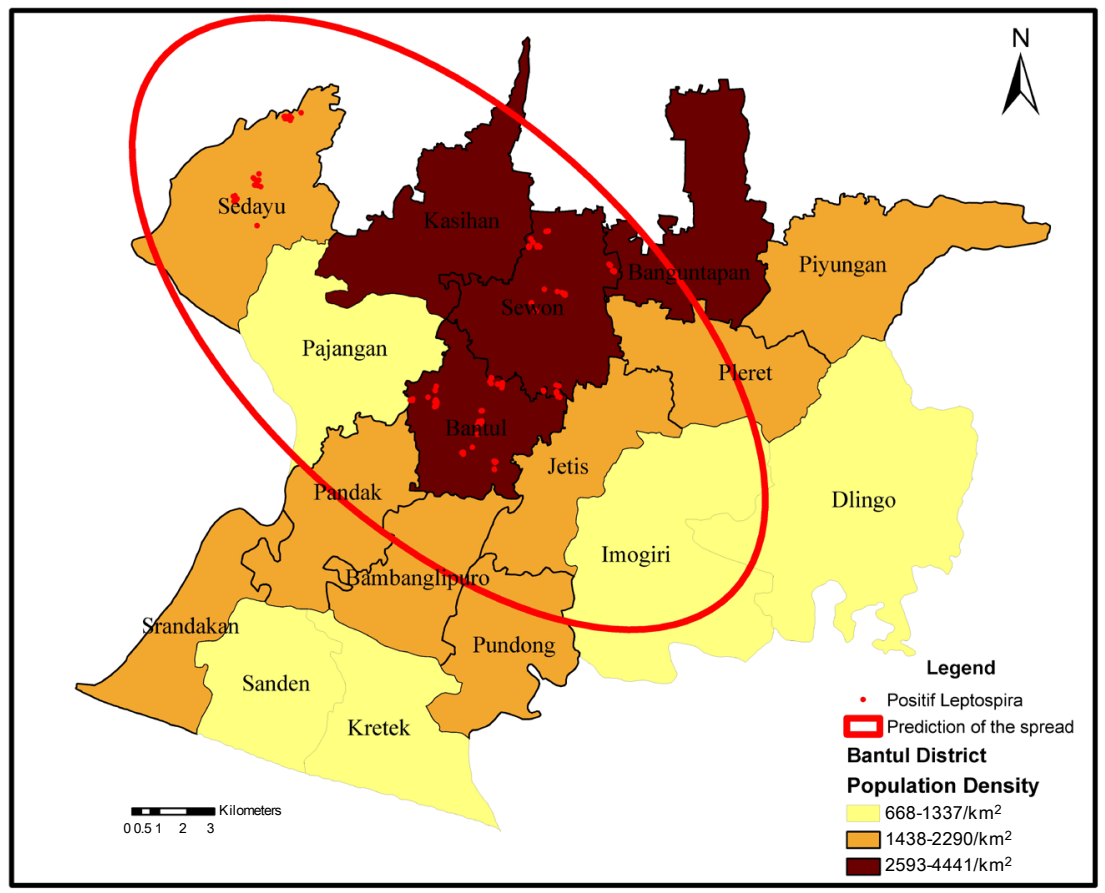

Figure 6. Prediction of the spread of Leptospira in the district of Bantul. Analysis using CrimeStat program. Almost all districts of Bantul, Kulon Progo and Sleman regency and Yogyakarta City is an area that can be a spread of Leptospira. Light brown until dark brown, showing population density in Bantul district. The red circle as a regional distribution prediction Spira. The red dots indicate positive samples Spira. 
were formed and statistically significant with a p value $<0.001$. This prediction of distribution extends to southwest (Sleman district) from source deployment in Sedayu sub-district. Other predictions of distributions are to the southeast which will hit sub-districts in the southeast and south of the Bantul sub-district and partially Yogyakarta City.

\section{Acknowledgements}

Our thanks are extended to the Government of Bantul, Bantul Health Office and Sedayu health center, Bantul health center and Sewon health center who have been given permission and helped in data collection process. Not to forget we thank to Yogyakarta Health Laboratory, Center for Environmental Health Disease Control Surabaya, and BBPPVRP Salatiga, Central Java, volunteers who have been willing to participate in the study.

\section{References}

[1] Bharti, A.R., Nally, J.E., Ricaldi, J.N., Matthias, M.A., Diaz, M.M., Lovett, M.A., Levett, P.N., Gilman, R.H., Willig, M.R., Gotuzzo, E. and Vinetz, J.M. (2003) Leptospirosis: A Zoonotic Disease of Global Importance. The Lancet Infectious Diseases, 3, 757-771. http://dx.doi.org/10.1016/S1473-3099(03)00830-2

[2] McBride, A.J.A., Santos, B.L., Queiroz, A., Santos, A.C., Hartskeerl, R.A., Reis, M.G., Ko, A.I. and Santos, C. (2007) Evaluation of Four Whole-Cell Leptospira-Based Serological Tests for Diagnosis of Urban Leptospirosis. Clinical and Vaccine Immunology, 14, 1245-1248. http://dx.doi.org/10.1128/CVI.00217-07

[3] WHO (2007) Leptospirosis. Laboratory Manual.

[4] Levett, P.N. (2001) Leptospirosis. American Society for Microbiology, 14, 296-326.

[5] McBride, A., Athanazio, D., Reis, M. and Ko, A. (2005) Leptospirosis. Current Opinion in Infectious Diseases, 18, 376-386. http://dx.doi.org/10.1097/01.qco.0000178824.05715.2c

[6] Matthias, M.A., Ricaldi, J.N., Cespedes, M., Diaz, M.M., Galloway, R.L., Saito, M., Steigerwalt, A.G., Patra, K.P., Ore, C.V., Gotuzzo, E., Robert, H., Levett, P.N. and Vinetz, J.M. (2008) Human Leptospirosis Caused by a New, Antigenically Unique Leptospira Associated with a Rattus Species Reservoir in the Peruvian Amazon. PLOS Neglected Tropical Diseases, 2, 1-12. http://dx.doi.org/10.1371/journal.pntd.0000213

[7] Michna, S.W. (1970) Leptospirosis. Veterinary Record, 86, 484-496. http://dx.doi.org/10.1136/vr.86.17.484

[8] Faine, S., Adler, B., Bolin, C. and Perolat, P. (1999) Leptospira and Leptospirosis. 2nd Edition, Medisci Press, Melbourne.

[9] Ido, Y., Hoki, R., Ito, H. and Wani, H. (1979) The Rat as a Carrier of Spiroci-I Ta Ictero-Hiemorrhagi E, the Causative Agent of Weil's Disease (Spiroch./Etosis Icterohiemorrhagica). Tokyo Iji-Shuho.

[10] Chappel, R.J., Prime, R.W., Millar, B.D., Jones, R.T., Cutler, R.S. and Adler, B. (1998) Prevalence and Geographic Origin of Pigs with Serological Evidence of Infection with Leptospira Interrogans Serovar Pomona Slaughtered in Abattoirs in Victoria, Australia. Veterinary Microbiology, 62, 235-242. http://dx.doi.org/10.1016/S0378-1135(98)00203-X

[11] Geisen, V., Stengel, C., Brem, S., Muller, W., Greene, C. and Hartmann, K. (2007) Canine Leptospirosis Infections? Clinical Signs and Outcome with Different Suspected Leptospira Serogroups (42 Cases). Journal of Small Animal Practice, 48, 324-328. http://dx.doi.org/10.1111/j.1748-5827.2007.00324.X

[12] Zakeri, S., Sepahian, N., Afsharpad, M., Esfandiari, B., Ziapour, P. and Djadid, N.D. (2010) Molecular Epidemiology of Leptospirosis in Northern Iran by Nested Polymerase Chain Reaction/Restriction Fragment Length Polymorphism and Sequencing Methods. American Journal of Tropical Medicine and Hygiene, 82, 899-903. http://dx.doi.org/10.4269/ajtmh.2010.09-0721

[13] Faine, S., Adler, B., Bolin, C. and Perolat, P. (1999) Leptospira and Leptospirosis. 2nd Edition, Medisci Press, Melbourne.

[14] Widarso, H., Wilfried, P. and Gasem, M. (2003) Pedoman Diagnosa dan Penatalaksanaan Kasus Penanggulangan Leptospirosis di Indonesia. Jakarta: Direktorat Jenderal PPM-PL, Subdit Zoonosis, Departemen Kesehatan.

[15] Rejeki, D.S.S. (2005) Faktor Risiko Lingkungan yang Berpengaruh Terhadap Kejadian Leptospirosis Berat. Universitas Diponegoro, Semarang.

[16] Gambiro and Wahyuni (2005) Laporan survey reservoir leptospirosis di Kabupaten Demak dan Kota Semarang Provinsi Jawa Tengah. Provinsi Jawa Tengah.

[17] Dinas Kesehatan Kabupaten Bantul (2013) Laporan Angka Kejadian Leptospirosis Tahun 2012.

[18] Syamsumin, D., Nurbeti, K., Syariffudin, V., Faisal, E., Rahayujati, B.T. and Santosa, T.B.H. (2010) Investigasi Keja- 
dian Luar Biasa (KLB) Leptospirosis di Kabupaten Bantul, Provinsi Daerah Istimewa Yogyakarta. FETP-FK UGM.

[19] Melani, S. (2010) Analisis Spasiotemporal Kasus Leptospirosis di Kota Semarang Tahun 2009. Fakultas Kedokteran, Universitas Diponegoro, Semarang.

[20] Asyhar, T. (2008) Analisis Spasial Faktor Risiko Lingkungan pada Kejadian Leptospirosis di Kota Semarang.

[21] Sunaryo (2009) Kajian Berbasis Citra Penginderaan Jauh dan Sistem Informasi Geografis untuk Pemetaan dan Analisis Faktor Risiko Leptospirosis (Studi Kasus di Kota Semarang, Provinsi Jawa Tengah). Fakultas Geografi Universitas Gadjah Mada, Yogyakarta.

[22] Fuadi, A. (2012) Hubungan Ternak Sapi Sebagai Reservoir Leptospira dengan Kejadian Leptospirosi pada Peternak di Kabupaten Bantul.

[23] Dohoo, L., Martin, W. and Stryshn, H. (2003) Veterinary Epidemiologic Research. National Library of Canada, Canada, 47-49.

[24] Rochman, D., Sukarna and Suwalan (1999) Pola perkembangbiakan tikus sawah Rattus argentiventer pada berbagai daerah berpola tanam padi-padi di subang. Penelitian Pertanian, 2, 77-80.

[25] Ristiyanto (2007) Sosialisasi Pengendalian tikus untuk pencegahan leptospirosis. Balai Besar Penelitian dan Pengembangan Vektor dan Reservoir Penyakit, Badan Penelitian dan Pengembangan Kesehatan, Departemen Kesehatan RI, Salatiga.

[26] Smythe, L.D., Smith, I.L., Smith, G.A., Dohnt, M.F., Symonds, M.L., Barnett, L.J. and Mckay, D.B. (2002) A Quantitative PCR (TaqMan) Assay for Pathogenic Leptospira spp. BMC Infectious Diseases, 2, 1-7 http://dx.doi.org/10.1186/1471-2334-2-13

[27] McBride, A.J.A., Santos, B.L., Queiroz, A., Santos, A.C., Hartskeerl, R.A., Reis, M.G. and Ko, A.I. (2007) Evaluation of Four Whole-Cell Leptospira-Based Serological Tests for Diagnosis of Urban Leptospirosis. Clinical and Vaccine Immunology, 14, 1245-1248. http://dx.doi.org/10.1128/CVI.00217-07

[28] Anies, Hadisaputro, S., Sakundarno, M. and Suhartono (2009) Lingkungan dan Perilaku pada Kejadian Leptospirosis. Media Medika Indonesiana, 43, 306-311.

[29] Lestariningsih (2002) Kelainan Ginjal pada Leptospirosis. In: Budi, R., H., G. and Muchlis, A.U.S., Eds., Kumpulan Makalah Simposium Leptospirosis, Universitas Diponegoro, Semarang, 47-53.

[30] Murtiningsih, B. (2003) Faktor resiko kejadian leptospirosis di provinsi daerah istimewa yogyakarta dan sekitarnya.

[31] Agustini, M. (2011) Environmental of Leptospirosis Endemic Area at Sumbersari Village, Moyudan Subdistrict, Sleman Regency Yogyakarta Special Region Province. Gadjah Mada University, Yogyakarta.

[32] Widarso, H., Husen, G., Wilfried, P., Tato, S., Endang, B., Septiawatichita and Pranti, S.M. (2005) Pedoman penanggulangan Leptospirosis Di Indonesia. Sub Ditrektorat Zoonosis. Direktorat Jenderal Pemberantasan Penyakit Menular dan Penyehatan lingkungan Dep Kes RI.

[33] Simanjuntak, G., Koesharjono, C. and Hardjoutomo, S. (1986) Leptospirosis di daerah transmigrasi Kuala Cinaku propinsi Riau tahun 1981. Penyakit Hewan, 18, 6-13.

[34] Priyanto, A., Hadisaputro, S., Santoso, L., Gasem, H. and Adi, S. (2008) Faktor-Faktor Risiko Yang Berpengaruh Terhadap Kejadian Leptospirosis (Studi Kasus di Kabupaten Demak). Universitas Diponegoro, Semarang.

[35] Haake, D.A., Dundoo, M., Cader, R., Kubak, B.M., Hartskeerl, R.A., Sejvar, J.J. and Ashford, D.A. (2002) Leptospirosis, Water Sports, and Chemoprophylaxis. Clinical Infectious Diseases, 34, 40-43.

[36] Ikawati, B. (2010) Analisis Karakteristik Lingkungan Pada Kejadian Leptospirosis di Kabupaten Demak Jawa Tengah Tahun 2009. Media Kesehatan Masyarakat Indonesia, 9, 33-40.

[37] Faine, S. (1982) Guidelines for the Control of Leptospirosis. Department of Microbiology Monash University, Melbourne, 1-200.

[38] Barcellos, C. and Sabroza, P.C. (2001) The Place behind the Case: Leptospirosis Risks and Associated Environmental Conditions in a Flood-Related Outbreak in Rio de Janeiro (O lugar do caso: Leptospirose e riscos associados a condições ambientais durante o surto de 1996 na Zona Oeste do Rio de Janeiro). Cadernos de Saúde Pública, 17, 59-67.

[39] Urmimala, S. (2002) Population Based Case Control Investigation of Risk Factor for Leptospirosis during an Urban Epidemic. American Journal Tropical Medicine and Hygiene, Salvador, 605-610.

[40] Priyambodo, S. (1995) Pengendalian Hama Tikus Terpadu. PT Penebar Swadaya, Jakarta.

[41] Nurbeti, M. (2012) Kasus-Kasus Leptospirosis Di Perbatasan Kabupaten Bantul, Sleman, Dan Kulon Progo: Analisis Spasial. Universitas Gadjah Mada, Yogyakarta.

[42] Dinas Kesehatan Kabupaten Bantul (2012) Laporan Angka Kejadian Leptospira Tahun 2011. Bantul. 
Scientific Research Publishing (SCIRP) is one of the largest Open Access journal publishers. It is currently publishing more than 200 open access, online, peer-reviewed journals covering a wide range of academic disciplines. SCIRP serves the worldwide academic communities and contributes to the progress and application of science with its publication.

Other selected journals from SCIRP are listed as below. Submit your manuscript to us via either submit@scirp.org or Online Submission Portal.
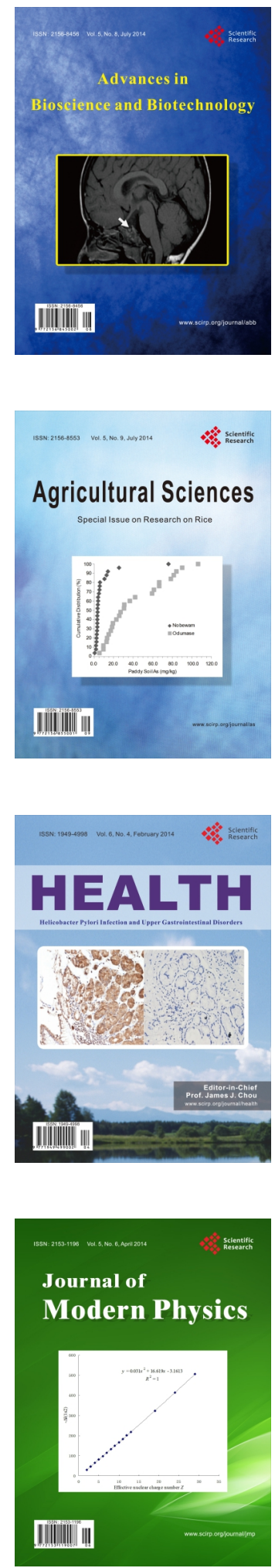
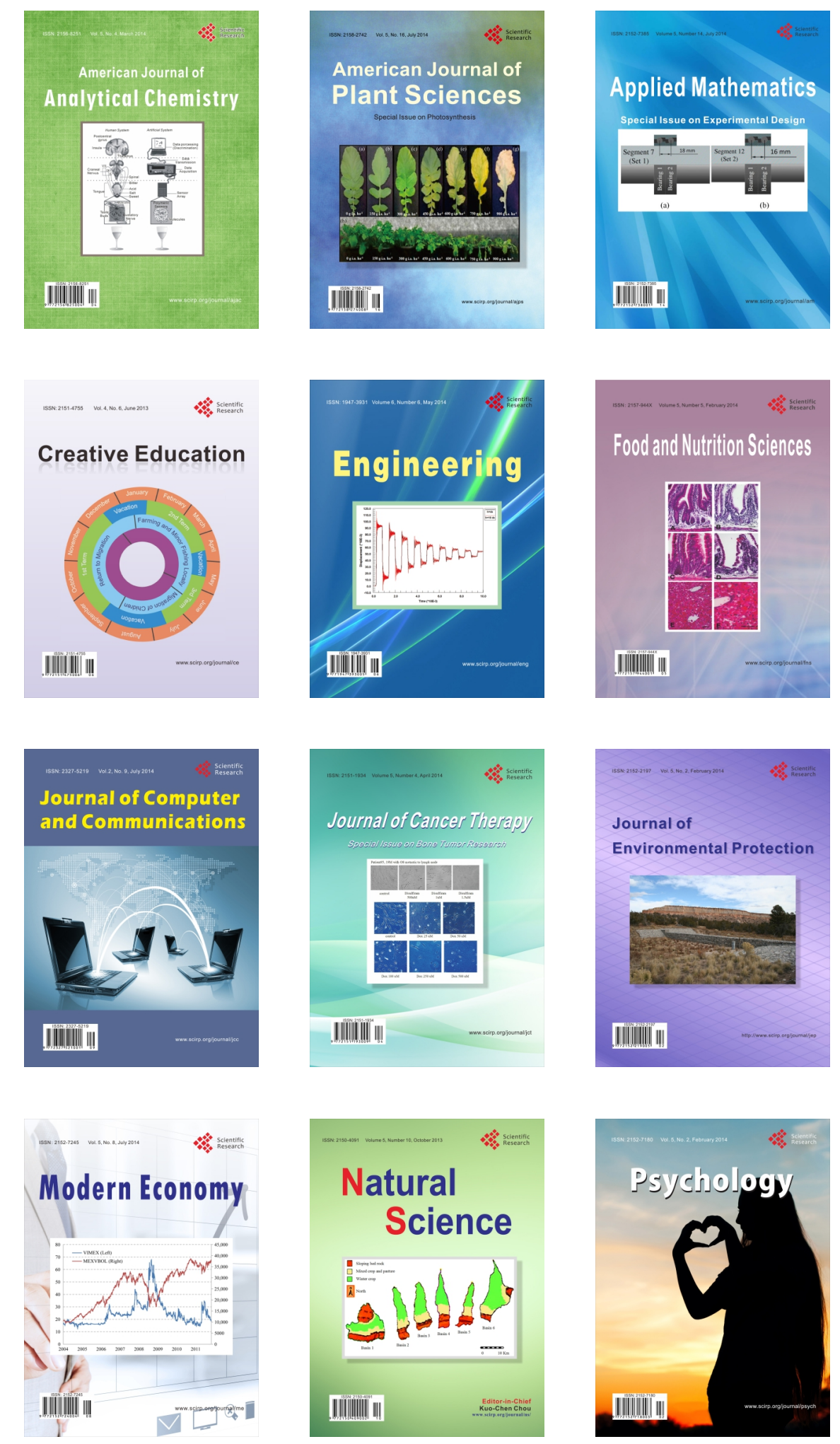